\title{
The rush for land in Africa: Resource grabbing or green revolution?
}

\author{
Ward Anseeuw* \\ CIRAD/University of Pretoria, South Africa
}

\begin{abstract}
The article details features and implications of the global land rush, with particular focus on Africa. Data and analyses of the 'Land Matrix' project help to provide an overview of these land-based investments, while locally implemented case studies in the framework of the 'Commercial Pressures on Land' project facilitate the assessment of implications related (or not) to the question of Africa's green revolution. By emphasising the need to go beyond the land acquisition phenomenon and its direct consequences, it re-contextualises the rush for land and relates it to broader dynamics of agrarian transformation in Africa. While the present rush for land may represent a revitalisation of Africa's agricultural sector, it is doubtful that this revolution benefits the continent overall.
\end{abstract}

Keywords: Africa; large-scale land investments; green revolution; agriculture; agrarian change

Growing demand for food, animal feed, fuels and fibre, combined with a shrinking resource base, the liberalisation of trade and investment regimes and increased price volatility, are among factors causing increased commercial pressures on land and fuelling a new global rush for land. ${ }^{1}$ This rush primarily affects agrarian economies, mainly in Africa and Asia. Lands that only a short time ago seemed marginal to investment interest are now being sought by international and national investors and speculators in quantities hitherto unseen. As such, growing foreign direct investments (FDI) in agriculture and a multiplication of investment projects on the African continent can be observed. For instance, in 2008, FDI directed to the African continent reached $\$ 87.6$ billion ( $27 \%$ higher than the previous year), of which a third (i.e. $\$ 27$ billion) went towards the mining and agricultural sectors in sub-Saharan African countries. ${ }^{2}$

According to the UN Food and Agriculture Organization (FAO), agricultural production in the developing countries will need to double by 2050 in order to feed the projected world population. ${ }^{3}$ The investment flow towards agriculture, particularly in Africa - a sector severely neglected since the 1960 s - is thus certainly necessary. However, several questions remain: how inclusive are these investments? Are the recipient African countries benefiting from these renewed flows of FDI? Do these investments constitute a green revolution ${ }^{4}$ in Africa or do they merely represent another resource-grabbing era in the continent's history? In-depth analysis of the broader phenomenon is a step towards better understanding the present land rush and its implications. With the spirit of optimism driving massive flows, yet potentially putting livelihoods and food security at risk and shaping the future of global agriculture, there is an urgent need to take stock of the real outcomes for all

*Email: ward.anseeuw@up.ac.za 
those involved. The objective of this paper is to go beyond a descriptive analysis of the land rush phenomenon, and to reflect on how the present investments into agriculture in Africa benefit (or beleaguer) the continent.

The article is based on results from several empirical projects in which the author is engaged. Based on primary data and field research, it presents a synthetic reflection, embedding local practices and processes into broader dynamics. The paper will first detail the features of the global land rush and offer an in-depth analysis of the processes at stake, with particular focus on Africa. Utilizing the analysis of the 'Land Matrix' project, ${ }^{5}$ this will enable a presentation of the nature of these land-based investments. A second section, based on case studies drawn from the 'Commercial Pressures on Land' project, ${ }^{6}$ will focus on the implications related (or not) to Africa's green revolution. By emphasising the need to go beyond the land acquisition issue and its direct consequences, the article re-contextualises, in the third section, the rush for land and relates it to broader dynamics of agrarian transformations in Africa.

\section{Global features of the rush for land - Africa, the most targeted continent}

The most recent and well-informed data emerging from the Land Matrix provide evidence that the scale of the land rush phenomenon is larger than previously assumed. As of December 2011, the Land Matrix contains reports of 2012 land deals, amounting to $228,130,787$ hectares of land worldwide. ${ }^{7}$ This includes all reported cases, identified in any source (e.g. press, research reports, government websites), at all stages of progress (including requests, negotiations/not signed yet, signed and effectively implemented deals and abandoned ones) and covering all sectors, in both developing and developed countries. To provide an idea of the scale of the rush, land reportedly under investment interest is equivalent to the combined surface area of Western Europe. These results are between four and five times more than the assessment of the World Bank's 2010 report, which presents a figure of 46,600,000 hectares as reported in the press between October 2008 and August 2009. ${ }^{8}$

Preliminary analysis from an ongoing cross-verification exercise suggests, however, that only about one-third of the reports regarding land investments could be cross-checked: 1107 deals (55\% out of the total reported number) covering a total of $67,042,000$ hectares $\left(29 \%\right.$ of reported number of hectares). ${ }^{9}$ These are also at different negotiation and implementation stages: applications may have been filed, negotiations can be on-going, signature and implementation can be effective, but deals can also be abandoned (Figure 1).

The identification and verification of land acquisition cases in the media and through other sources confirm that a high proportion of cases never reach fruition. Regarding agriculture, for example, $31.5 \%$ out of the total of reported cases resulted in an effective signature and concrete transfer of land. Similar analysis for the surface/hectares is more difficult, as only proportions of the effectively acquired lands might be under production. This being said, projects that have started producing effectively cover $25.2 \%$ of the reported surface. ${ }^{10}$ The difference between the reported cases and implemented/signed deals is mainly linked to managerial and technical difficulties related to the implementation of large land deals in often difficult ecological, political, bureaucratic and socio-economic environments. It may also reflect the strategic positioning of investors who are aiming to secure land even in the absence of specific investment plans. ${ }^{11}$ The gap between announcements and implementation should not lead to complacency. Announcements, negotiations and 

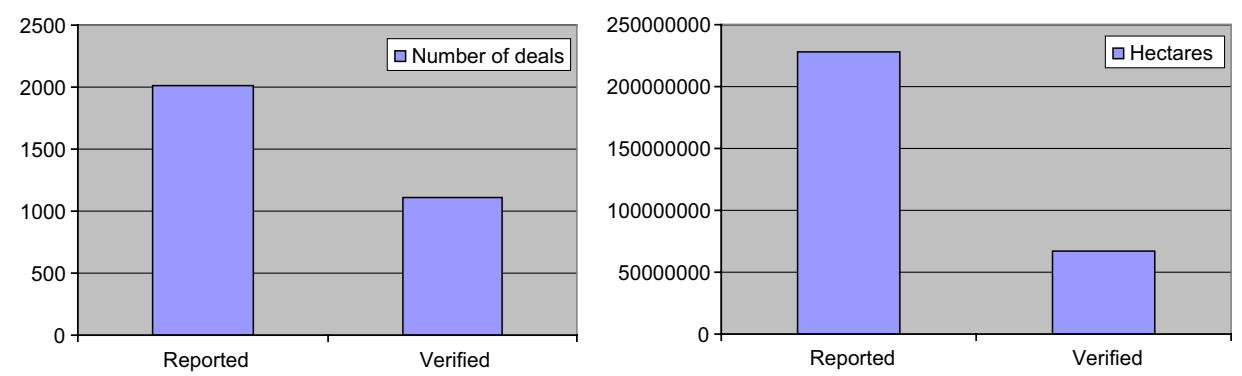

Figure 1. The scale of reported and verified land acquisitions in the world.

Source: The Land Matrix, 2011 data.

Note: 'Reported' indicates 'reported in any source of information', whereas 'verified' means that the reported data has effectively been cross-checked. For more information see the Land Matrix website.

certainly contracts signed but not implemented may still exacerbate commercial pressure on land and lead to a weakening of land rights for the local population. ${ }^{12}$ Several case studies show that negotiations and contracts without effective implementation may still translate into loss of land for local groups, even if the project is not implemented after all - as has been the case with the Bechera agricultural development project in Ethiopia. ${ }^{13}$

\section{Africa is the prime target of the land rush}

Out of the total of the publicly reported deals (at all stages), about 161.7 million hectares are located in Africa (948 land acquisitions), while some 42.7 million hectares are reported in Asia and 17.6 million hectares in Latin America. The remaining 5.4 million hectares concern other regions, particularly Eastern Europe and Oceania. Of course, as noted by Cotula, ${ }^{14}$ the regional pre-eminence of Africa could reflect the strong media interest in the continent's deals. For example, some food-importing African countries that are or were major recipients of food aid, such as Ethiopia and Sudan, have attracted extensive media attention, while scattered evidence suggests that there has been strong investor interest in Australia, New Zealand, North America and Eastern Europe (see Figure 2).

Although foreign investors target a large number of countries, 11 countries concentrate $70 \%$ of the reported targeted surface. Among those 11 countries seven are
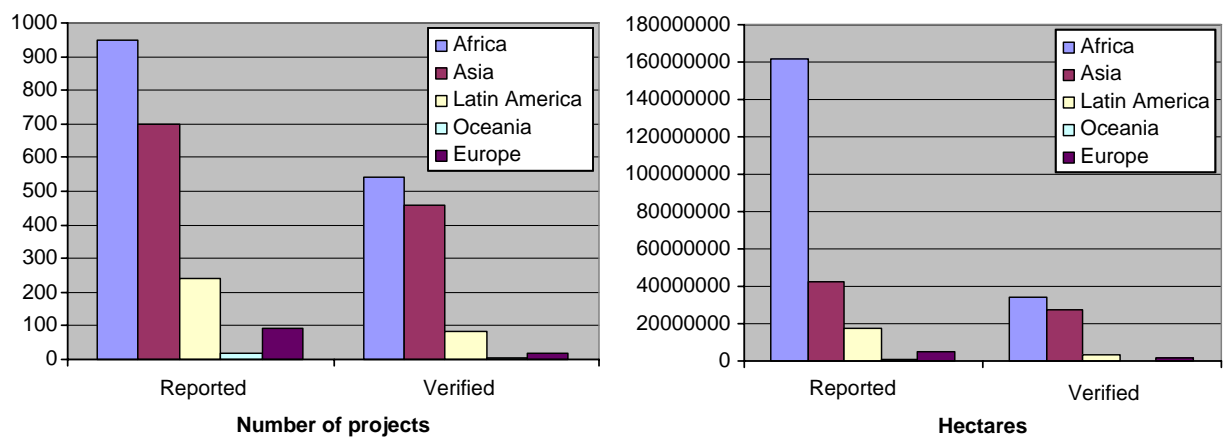

Figure 2. Reported and verified deals by region.

Source: Land Matrix, 2011 data. 


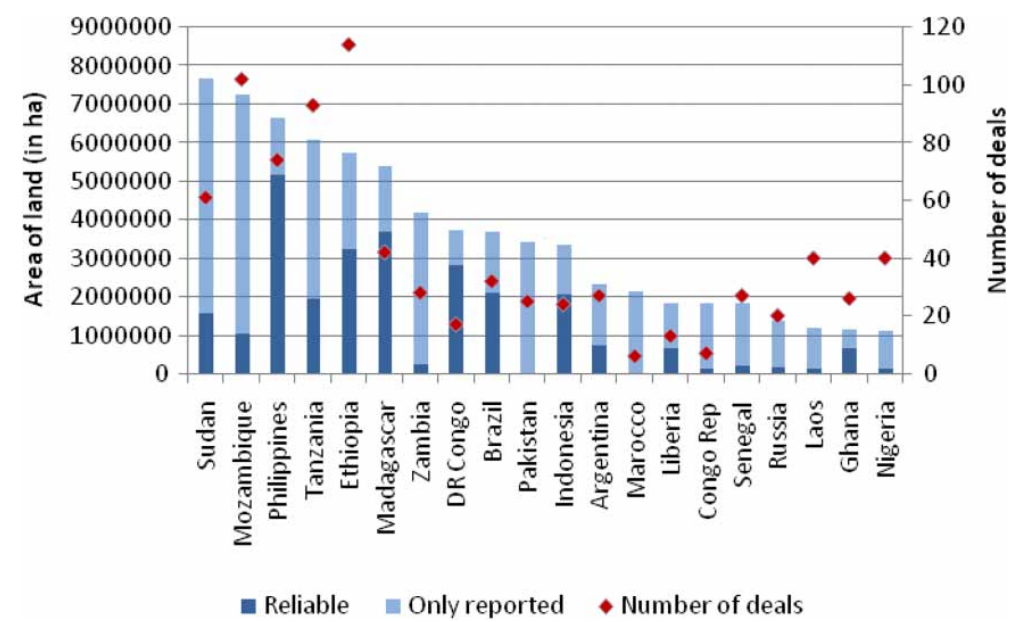

Figure 3. Countries with highest land-based investments.

Source: Land Matrix, 2011.

African ${ }^{15}$ (Figure 3). African countries also represent half of the countries in the top 20 most targeted countries for land acquisition meant for agricultural production. Countries such as Sudan, Ethiopia, Mozambique, Zambia, the Democratic Republic of Congo and Tanzania are facing a large proportion of the reported demand for land by foreign actors, in terms of both cumulative size and number of projects.

\section{The rush for land is not limited to agriculture}

With the pace of land acquisitions peaking in 2008 after the food price crisis, ${ }^{16}$ much of the recent focus has been on investments in agricultural production for farmland. ${ }^{17}$ Agricultural production is indeed the primary driver behind the rush for land (accounting for $69 \%$ of reported deals), with food crops accounting for $31 \%$ of the number of announced projects, biofuels $29 \%$, other non-food crops $6 \%$ and livestock $3 \%{ }^{18}$ (Figure 4). However, other sectors are not insignificant: forestry and carbon sequestration, mineral extraction and tourism account for a combined $11 \%$. The latter are not always directly linked to the recent land acquisition phenomenon (many of the

\section{Number of verified deals}

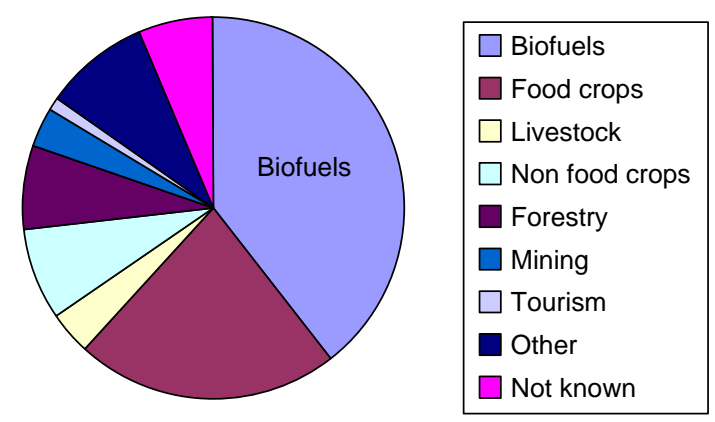

Figure 4. The different sectors invested in the framework of recent phenomenon of the rush for land.

Source: Land Matrix, 2011. 
forest concessions existed prior to 2007-2008), but their growing importance in absolute terms currently generates increased commercial pressure on land.

This being said, the importance of agriculture does not mean that the large majority of investments focus on food crops. Indeed, food crops account for only $31 \%$ of the agricultural projects, representing $21 \%$ of the total land acquisitions. In Africa, $38 \%$ of the land investments are geared towards biofuels, whereas food crops tend to be more important in Asia ( $25 \%$ compared with $21 \%$ biofuels projects). In Latin America, on the other hand, acquisitions tend to be more mining-oriented $(17 \%) .{ }^{19}$ This observation is distressing as most of the African countries are food-importing countries, reflecting a certain contradiction between the region's investment needs and investment realities.

\section{Africa's investment remains inter-continental}

A large proportion of investment flows continue to originate from Western countries. However, emerging economies are rapidly becoming major investors. While much public attention has been paid to the role of China, India and South Korea, investors from countries such as the United Arab Emirates, Qatar, Bahrain as well as Thailand, Malaysia, South Africa and Brazil are also active in land deal negotiations. ${ }^{20}$ While these shifting investment patterns suggest that regionalism and new South-South cooperation patterns may be on the rise, Africa's investment still mainly originates from outside the continent: $71 \%$ of Africa's farmland investments originate from outside the continent, against $9 \%$ in Asia. If there is an increase of investment flows into Africa's farmland sector, it remains foreign driven. This in turn raises issues of sovereignty for African states ${ }^{21}$ (Figure 5).

\section{The investment dynamics - new actors, new investment models}

The renewal of these investment dynamics mainly concerns three types of actors. ${ }^{22}$ The first category of investors is the traditional Western food-producing, processing

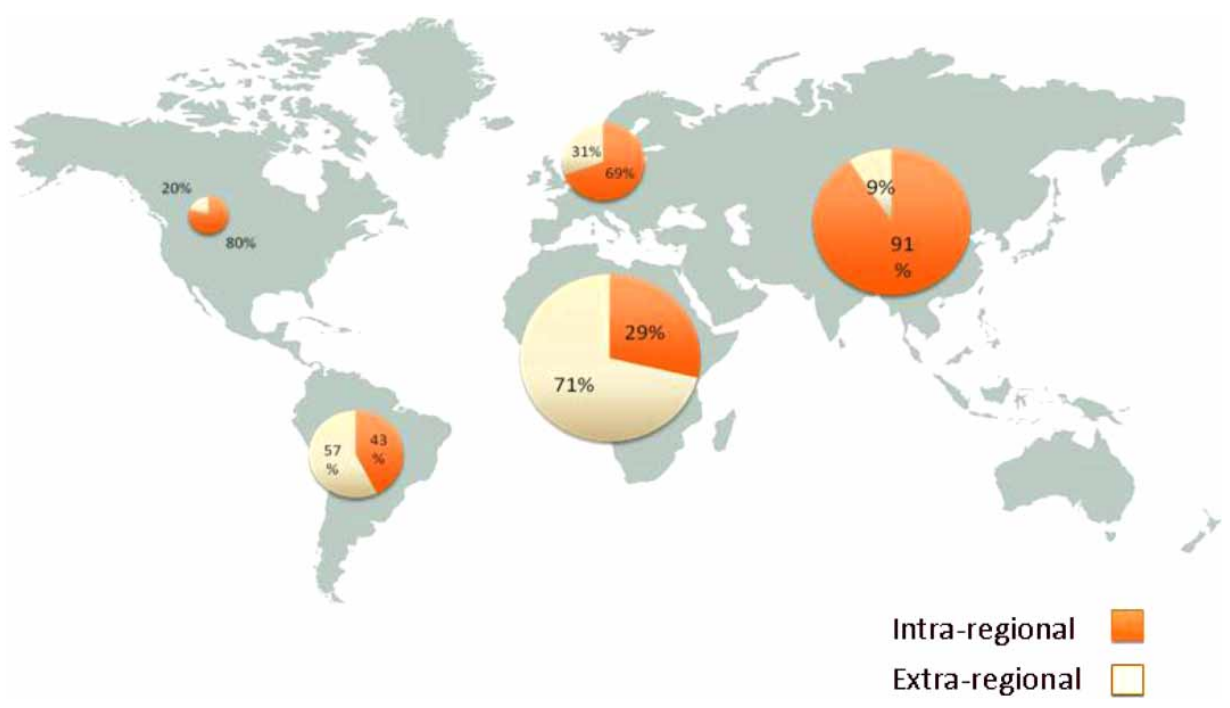

Figure 5. Origin of investment per region.

Source: Land Matrix, 2011. 
and exporting companies seeking to 'square the market'. They mainly represent Western, private investors. A practice that has been growing is the partial integration of primary production, mainly to secure access to primary production. Companies that used to rely on the market to access their produce are presently engaging (often for about $30 \%$ of their needs) in primary production. ${ }^{23}$

A second category of investors concerns land- and water-scarce populous and capital-rich countries. It is composed of countries such as China ( $20 \%$ of the world population for only $9 \%$ of the world's arable land) and other capital-rich but food insecure Asian countries (e.g. South Korea) and the Gulf states. These countries coordinate their investments offshore, mainly through direct government involvement, state-owned enterprises or sovereign wealth funds. The major characteristic of this model is the establishment of parallel value-chains in order to avoid depending on markets that have become too volatile.

The third and last category consists of outsiders to the traditional farming sector. It concerns financial actors, commercial banks, investment/pension/hedge funds and asset management companies seeking to diversify their portfolios. ${ }^{24}$ Owing to their anticipation that the agricultural sector is an investment for the future, they engage accordingly in 'Malthusian oriented speculations'. Besides being characterised by its speculative character, their involvement is often characterised by the implementation of finance value chains, where financial services are frequently combined with marketing activities and possibly technical support. ${ }^{25}$ Thanks to near total control of these actors over the circulation of capital and information flows, this approach aims at limiting transaction costs and the risks inherent in the agricultural activity, leading to tight integration and internalisation of production. ${ }^{26}$

A common characteristic of this increasing control over land-based productive cycles - primary agricultural production in particular - is a far-reaching trend of vertical integration. Upstream (including financing) and downstream activities (distribution and commercialisation) are undergoing an ever-increasing concentration process, to the benefit of some macro-actors. In addition to partnerships, contractualisation and other similar arrangements, total integration of these activities allows dominant actors to widen their control over the entire productive cycle. ${ }^{27}$ Unlike the well-known down- and upstream integration patterns of monopolistic agribusinesses illustrated by Cargill or Monsanto, ${ }^{28}$ the present integration process (including agricultural production) is initiated from outside the agricultural sector. It is driven by financial actors and engineering companies. Models vary according to the type of organisation (e.g. contracts, production outsourcing) and the actors involved (e.g. banks, intermediaries, investment funds). The approach is not new, and several agricultural export sub-sectors (such as coffee and cotton) are already structured according to this model. However, over the past few years, this financial strategy has been applied more widely, both geographically and at the level of the concerned value-chains (e.g. cereal). ${ }^{29}$

\section{Beyond loss of land: agrarian change and social transformation}

The effects of large-scale land acquisitions and wider commercial pressures on land can be conceptualised along several dimensions. They may be felt at a local level, at a national one, or globally through world markets and global ecosystems. They can involve direct outcomes such as new employment or loss of access to a resource, but can exert indirect impacts such as changed food security status, both local and 
elsewhere. Also, people may be affected in different ways: food production and availability, income, their way of living and economic development. Also important are issues of dignity, self-determination and the right of people to decide their own path of development and to control their own food systems. ${ }^{30}$ Lastly, commercial pressures on land have different impacts on different groups of people. Such groups include international land acquirers and host country elites, the population of host countries and other countries, and the local communities directly affected. ${ }^{31}$ However, it is also vital to remember that there are divisions and power relations within these groups. It is the poor who are most likely to be negatively affected, as are pastoralists and forest-dependent people.

Although based on sound experience, observations from the field should be treated with caution for several reasons. Firstly, the cases observed were often in the initial stages of investment. While adverse impacts tend to be concentrated at the initial stages of project implementation (e.g. loss of local land rights), some of the claimed benefits (e.g. public revenues, employment) will only fully materialise in the future once investment projects are operating at full scale. Secondly, case study evidence is strongest on local impacts, and less strong on wider economic impacts, which would require a different set of methodologies. Thirdly, much of the research on which this section is based took place in contexts where foreign investment in natural resources is treated as an unalloyed good by government and other powerful actors. Therefore, many of the contributing organisations have sought to draw attention to some of the overlooked or deliberately ignored downsides of investment practices, particularly those that affect marginalised land users who otherwise have little voice within public debate and policy-making. Finally, the case studies of landbased investments relate to an extremely diverse range of geographic, sectoral and practical specificities. As a result, the observations may not be applicable in different contexts. The evidence presented here is therefore indicative rather than conclusive and constitutes a preliminary reflection on possible implications.

\section{Expectations for host countries and populations rarely fulfilled}

The renewed interest of a diversity of investors seems to represent an opportunity for host governments to attract private, national and/or international capital. As such, in view of reduced public spending and Official Development Assistance (ODA), these investors are perceived as solutions for the discarded agricultural and rural sectors. For the first time since the late 1970s, there is an opportunity for African governments to attract investment towards a sector that had been gradually relegated to the bottom of both the public policy agenda as well as private investors' priorities. As such, these initiatives are presented as contributing to the countries' revitalisation of their agricultural sectors directly through large-scale investment or through a positive pull-effect integrating the host countries' small-scale farming sectors). It is stated that this will enhance their national food security situation and develop rural infrastructure. ${ }^{32}$ In reality, in many cases, these processes tend to fuel unrealistic expectations on the part of the host countries and local populations.

Not only is the production often not developed according to plans and expectations, but the accompanying promises of infrastructure development and employment creation, among others, are also generally not fulfilled. ${ }^{33}$ Several reasons account for this. Firstly, some operators may have underestimated the managerial and technical difficulties related to the implementation of large land 
deals in what often prove to be difficult ecological, political, bureaucratic and socioeconomic environments. This issue is likely to be particularly relevant to operators who do not have an established track-record in agriculture. Secondly, investors may not be successful in gaining the land allocations and investment conditions that they covet, resulting in the investor pulling out. This was reportedly the case in several investment projects in Mali and the Daewoo case in Madagascar. ${ }^{34}$ Brautigam and Xiaoyang also give the example of a Chinese parastatal backing out of its allegedly well-received request to access up to 3 million hectares of forested lands to grow oil palm, following feasibility studies that showed insufficient transport and infrastructure support to and from the area. ${ }^{35}$ Thirdly, as earlier mentioned, some public announcements of land deal negotiations reflect the strategic positioning of investors who seek to secure land, even in the absence of specific short-term investment plans, as they expect its price to increase. ${ }^{36}$

Loss of access to productive resources can have negative effects on income and compel the affected populations to seek other means of living. On the other hand, investments can be a source of income for local populations, through wage employment, share-cropping and outgrower schemes, or as a result of locally negotiated land leases. However, in each of these instances, the income possibilities depend on the terms that have been negotiated, and thus on the negotiating power of the relevant parties. In other words, sharing profit between investors and local populations depends on the level of wages, leases and other negotiated contractual terms, as much as the price of agricultural supplies provided by small-scale growers. In turn, these aspects are affected by varying degrees of control over resources and market conditions (such as monopoly or monopsony structures), and by negotiating power.

In the majority of cases, only the better-off local farmers manage to adapt to the changing context and benefit from incoming investment - usually through outgrower or sharecropping schemes. The others, particularly those who lose their land, face the risk of a loss in income. This situation is clearly exemplified by a Rwandan case study in which only a small number of farmers - those who were commercially oriented before the arrival of the agribusiness company - were able to retain access to land and work as outgrowers with the agribusiness. The others took up employment on the plantation or elsewhere. The study suggests that both groups considered themselves to be poorer than they were before the takeover by the agribusiness: the outgrowers complained about the conditions imposed by the agribusiness, which benefitted from its monopolistic position, while the labourers were impoverished and lamented the poor labour conditions. ${ }^{37}$

Several studies also suggest that the anticipated jobs do not necessarily materialise. This is partially because investments are often capital intensive, but also because local populations are not well integrated in the investment projects. Moreover, benefits in the form of local jobs are likely to be limited, where investors can hire imported labour or, worse, can come with their own labour. ${ }^{38}$ This commonly applies to recruitment for managerial and skilled positions, while locals are confined to precarious, seasonal or low-paid jobs. In addition, when local people are employed, labour relations tend to be strained. ${ }^{39}$ These observations are all the more significant when the lack of employment alternatives is exacerbated by reduced access to land and the affected populations cannot disassociate themselves from the investing companies. 
Lastly, benefits at national level need to be nuanced. Most of these investments do not focus on providing food and primary commodities for local communities or for export on international markets. They directly relate to the investor country through integrated and vertically integrated production processes. Such offshore production schemes, in addition to the lack of local integration (import of machinery and labour), also fail to inject money into local economies and to contribute to local food production and security. These current mass investments in land-based production are thus not directly integrating poor agrarian economies with the global economy. Instead, poor economies, while providing resources for the investors, remain in a client position. In these circumstances, host countries may find it difficult to exert their own priorities relating to agricultural development and national food security. Examples come from several of Africa's cereal-importing countries, where investors, mainly from the Arab countries, are producing and exporting cereals to enhance their own food security situation. ${ }^{40}$ In addition, several African countries tend to provide extensive benefits to investors. Critics argue that they have not attracted new FDI, but merely encouraged the shift of existing industry (foreign as well as domestic), eager to benefit from lower tax regimes. The outcome, they argue, is lost revenue given the exemptions and benefits granted at the expense of productive income. ${ }^{41}$

\section{Direct negative impacts on local populations and agrarian economies}

Local populations may also be negatively affected by incoming investments. Although it is still too early to fully assess the impact of many of these investments, some evidence is already available.

There is a widespread perception that much land is 'empty', 'available' or simply 'wilderness'. However, land that is not under permanent cultivation is more often than not the collective asset of rural communities under local tenure systems. These communally held lands, or 'commons', often constitute the land and resource asset of rural communities. Far from being idle or unused, such lands are in fact crucial elements in the system of customary or indigenous land holding and use. ${ }^{42}$ They are also major contributors to livelihoods. Pastoralists and forest-dependent people are particularly at risk given the nature of their land use and their need for large land areas to survive. ${ }^{43}$

In addition, although they claim to target marginal lands, acquirers are most interested in lands that are fertile, well-watered or with good rainfall, and have access to various infrastructure (road or rail access, electricity transmission, in close proximity to markets and settlements and to nearby export servicing centres). ${ }^{44}$ Not only is there significant competition between investors for these lands, but these areas are also likely to be under relatively intensive use by local people (for farming or any other livelihood-based activity). The case of the Nile basin is a good example, as control over land resources has become increasingly concentrated (Figure 6). ${ }^{45}$

In addition to this, the transformation from low input smallholder agriculture to large-scale, intensive and industrialised agriculture may imply a range of environmental consequences. These include land degradation, water pollution, excessive use of fresh water and heavy dependence on fossil fuels for machinery, fertiliser and pesticides, and increased emissions from storage and transportation. ${ }^{46}$ Meanwhile, the conversion of forested and uncultivated lands is associated with biodiversity loss, degradation, diversion of water from environmental flows and loss of ecosystem services such as the 


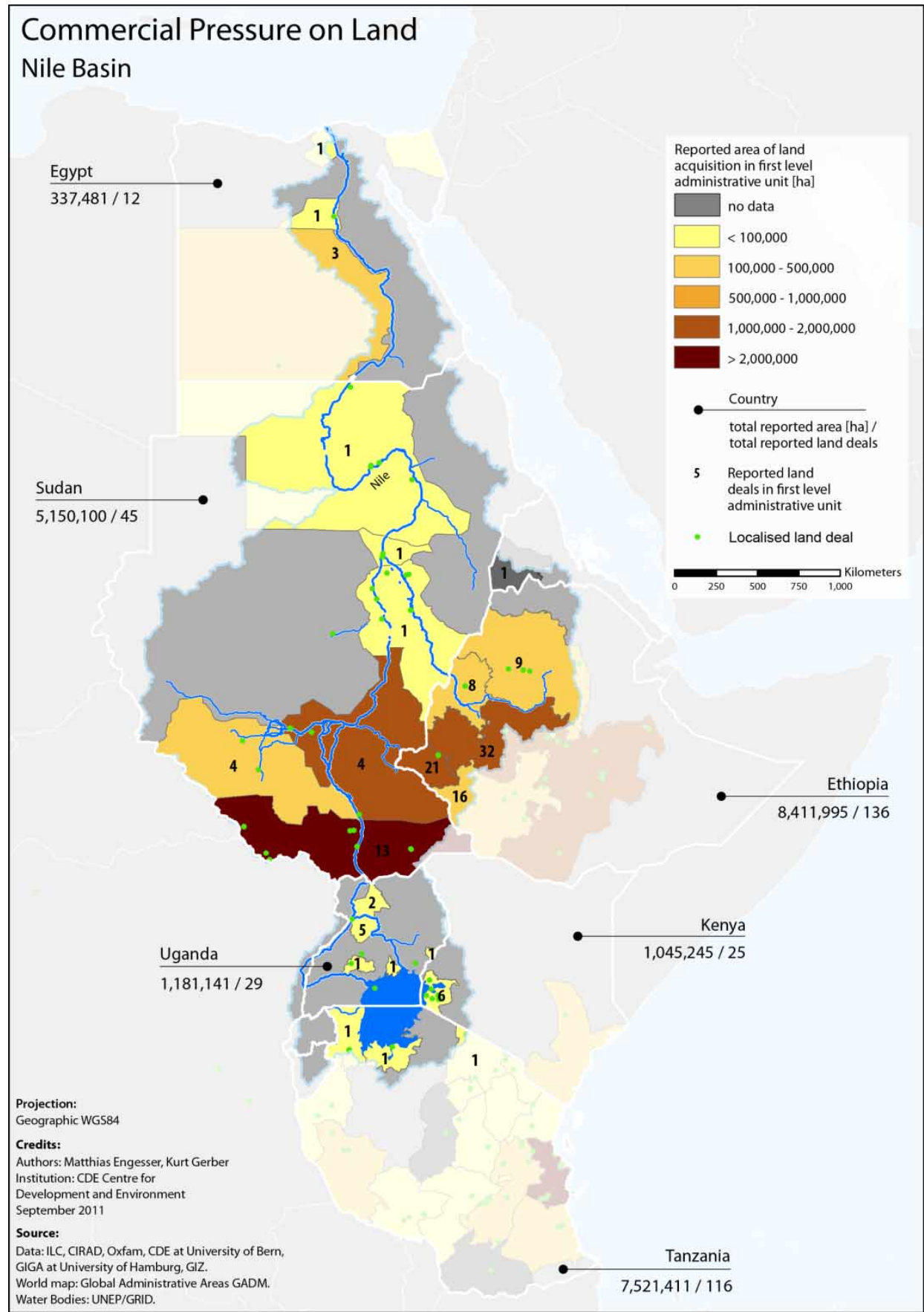

Figure 6. Land acquisition concentration in the Nile river basin. Source: The Land Matrix, 2011 data.

maintenance of soil and water quality and carbon sequestration. ${ }^{47}$ Several reports emphasise the depletion of forests: observations of deforestation are widespread in the context of increasing commercial pressures on land. ${ }^{48}$ 
Although some of the local populations can change activity and/or relocate to other lands, this often results in their exposure to less favourable productive and living conditions, thereby putting even more pressure on already fragile farming systems and livelihoods. Substantial evidence of this scenario was found in Bechera (Ethiopia), where sharecropping practices have been developed to allow access to land for those who have lost or cannot secure their own plots. These new practices are, however, often insufficient to meet basic food and needs, leading more vulnerable farmers to abandon their lands and migrate to urban areas. ${ }^{49}$ In Rwanda, it is the acquisition of fertile lands in the river valleys surrounding Kigali by a foreign company that has pushed the population towards less fertile lands situated on the hillsides. In each case, the displacement of populations as a result of land acquisitions - no matter what alternative provisions are made - generates important losses in terms of volume of production and income. ${ }^{50}$

\section{Further marginalisation of smallholder agriculture - exacerbating and entrenching the root causes of the land acquisition phenomenon}

The direct costs local populations face as a result of the rush for land are relatively straightforward: the poorest members of agrarian societies risk losing their only major assets, namely land, water and housing. However, in addition to this, the rush for land also has indirect consequences which highlight deeply rooted challenges to the sustainability of the living conditions of the rural poor. The rush for land is therefore more a symptom than a cause. These indirect or broader implications are often less directly observable, although they may have deeper roots. Since these often relate to the intrinsic characteristics of agrarian economies and societies, the potential impact on the poor is far greater than the direct implications of dispossession from property.

The land rush phenomenon represents only the tip of the iceberg, as it is part of wider land-related and agrarian dynamics. Land acquisitions per se tend to divert attention away from the changing dynamics of investment into agriculture and landbased activities, and, subsequently, from the broad transformation of agrarian societies. ${ }^{51}$ Going beyond the land rush is necessary to understand the far-reaching and profound agrarian changes, with significant consequences for farmers and traditional land owners and users. Four major structural tendencies may be identified: the financialisation and corporatisation of agriculture; the concentration and dualisation processes of the sector; speculation and its interface with the engagement of foreign powers; and, finally, the proletarisation of the African agricultural masses.

\section{Financialisation and corporatisation of agriculture}

As shown in the first section of this article, the land rush relates to new actors engaging in African agriculture. They originate from industrial or financial sectors, and engage as entrepreneurs, investors or even as pure speculators. The sources of capital also seem more and more exogenous to the agricultural sector. In addition to the provision of funds, these actors bring along new business strategies, as well as modes of actions and regulations that stem from other sectors. The resulting shifts contribute to redefining the contours of the agricultural sector and, both in Africa and globally, to its restructuring. The 'agricultural exception', reflected by the 
sector's separate negotiations within the World Trade Organization, is fading once and for all.

New agricultural development paradigms, which have repercussions that manifest both at national and international levels, hence tend to impose themselves. The increased role of banks and investment funds seems to lead to a 'financialisation' of agriculture according to which financial considerations tend to supersede the traditional socio-economic principles of the sector. ${ }^{52}$ This has been the case with the recent and unprecedented boom in agricultural speculation. ${ }^{53}$ Whereas speculation had previously been limited to being an internal and short-term phenomenon, since the food price crisis in 2008-2009 it has become associated with long-term strategies led by actors external to the sector.

The financialisation of the sector also contributes to a 'corporatisation' of the agricultural sector. In addition to industrialisation and mechanisation, this phenomenon involves a transformation of the production structures and their interactions. This, in turn, tends to be structured by and integrated within corporate structures. ${ }^{54}$ Increasingly, the agricultural value-chain is controlled by a single or a few dominant actors. The control over various segments along this chain is established either through direct acquisition or through contractualisation, resulting in a concentration of control by these macro-actors. While in South Africa the dominant actors include banks and former cooperatives, elsewhere other models engaging different macro-actors are emerging (e.g. multinational agribusinesses in several African countries, investment funds in Kenya and Mozambique). ${ }^{55}$ The organisation of agricultural production tends towards a strongly integrated structure, ${ }^{56}$ comparable to the management of industrial chains.

\section{Concentration and dualisation within the sector}

These evolutions contribute to strengthening dualism within the African agricultural sector. Whereas the macro-actors see their dominant positions strengthened, entire fractions of the (rural) African society are excluded from the resulting dynamics.

Two groups of actors seem to benefit in particular from the agricultural restructuring. First of all, the financial actors become the regulators of the sector, by directly controlling an increasingly large portion of primary production and by imposing their model on producers. By integrating the entire value-chain and by centralising the information flows, they anticipate the evolution of these markets, in particular the prices, and act as market arbitrators. ${ }^{57}$ The second group to benefit from the evolution of the production structures is the agricultural intermediaries. Indeed, the financial institutions intending to invest in the agricultural sector increasingly depend on the services of agricultural engineering and asset management companies. As managers of both the field operations and the financial transactions, these companies are capturing an increasingly large portion of the margins generated by agricultural activity.

The rush for land and the related process of financialisation and corporatisation of the agricultural sector are leading to a new regime characterised by the domination of a few large, international (food) business groups. ${ }^{58}$ This could lead to the marginalisation of the majority of African farmers owing to biased power relations and their confrontation with models of significantly higher productivity. ${ }^{59}$ Whereas the macro-actors of the food-processing industry see their dominant positions strengthened, entire segments of the (rural) African society are excluded 
from these dynamics. On the one hand, the small- and medium-sized farms (including South Africa's traditional commercial farmers, the bigger ones being able to sustain themselves) are being swallowed by corporate actors. On the other hand, family farming, and in particular the small-scale farmer, is stagnating in inert subsectors. Both parties have diverse financial, social and cultural resources that result in skewed relationships, ${ }^{60}$ which seem to extend beyond the traditional cleavages within the African agricultural sector. In South Africa, these evolutions tend to strengthen and deepen the dualist nature of the nation's agricultural sector. ${ }^{61}$ In other African countries, such as Mozambique, ${ }^{62}$ these dynamics result in a process of land concentration.

\section{Speculation and foreign powers}

The control of agricultural production by a small number of (often foreign) macroactors, not only raises the problem of concentration and dualisation of the sector, but also draws attention to the need to analyse this phenomenon within the framework of these actors' strategies. Indeed, the strong volatility of agricultural prices, perpetuated by the removal of stabilising mechanisms (e.g. market regulations), facilitates the economic agents' direct involvement in and control over agricultural regulation mechanisms. More specifically, speculation strengthens profit-oriented strategies, to the detriment of food security concerns in the countries where production effectively takes place. ${ }^{63}$ Furthermore, as foreign economic players establish control over an increasingly large part of the production, food sovereignty issues are being amplified. The food security, as much as the sovereignty of the producing countries, may be at stake. ${ }^{64}$

The UN Special Rapporteur on the Right to Food notes that a significant part of the volatility and the rise in prices during the late 2000s can be explained by the emergence of speculation on land and food stuffs. An essential role is attributed to the participation of powerful institutional investors (e.g. investment funds, pension funds and commercial banks). ${ }^{65}$ These entities are often foreign-owned with limited or no interest in the objectives of stabilisation, food security and food sovereignty. While the price volatility of agricultural commodities and the strategies of speculation raise problems related to the implementation of development programmes, they also emphasise questions regarding the regulation of the agricultural and financial sectors and regulatory frameworks in a large number of domains, including the functioning of the futures markets and foreign trade. They also lead to considerations related to national policies, the development of sector-based and financial strategies, and regional integration.

\section{Marginalisation, proletarisation and pauperisation of agricultural societies}

The emergence of such new production models generates numerous economic uncertainties, but it is their social impact that is most concerning. Indeed, one of the common characteristics of these innovations seems to be the increased marginalisation of producers and farm workers.

The incorporation of family-based producers by macro-actors has had detrimental effects for the former. Beyond the biased economic relationships detailed above, land owners find themselves incorporated into production chains in which they are isolated actors with no decision-making or directive power. The technical 
capital used is generally characterised by ever-increasing costs and does not belong to them but is made available by the management company. This situation results in a loss of autonomy and creates a dependency for the farmers, as they become unable to withdraw from these production relationships without losing access to the necessary financing and inputs. Although they often remain the land owners, their situation is increasingly similar to that of proletarian agricultural employees or of service providers.

These transformations impact the producer as economic agent, but also as a social actor. The corporatisation process disturbs social relationships and the traditional character of Africa's agricultural and rural environments. The family unit had constituted, until now, the basic structure around which African agricultural production was organised, on both smallholder and larger farms. The incorporation of autonomous family enterprises into entrepreneurial structures necessarily modifies the relationships within the agricultural sector. Beyond the producers and landowners, farm workers are also negatively affected. The recourse to agricultural technologies that require low, often seasonal, labour inputs tends to exacerbate the precariousness of farm working conditions. ${ }^{66}$

\section{Conclusion - a green revolution in Africa? Probably, but (at this stage) neither by nor for Africa}

Investor interest in African agriculture is on course to produce a revolution in this once-neglected sector. The revolution might be a green one, as the rush for land goes hand-in-hand with structural changes which, as described in this paper, might lead to increased agricultural productivity. ${ }^{67}$ It is, however, still too early to predict the final outcomes of this revolution.

What already seems clear is that this green revolution is not yet benefiting Africa, and definitely not Africa's rural masses. It is becoming apparent that the host economies remain significantly marginalised from the renewed investments in agriculture. The long-term nature of typical large-scale acquisitions effectively locks communities and smallholders out of land for several generations. This may bring about the end of cultivation and livestock rearing as traditional livelihoodsupporting activities in affected areas. While local populations are losing arable land, they also have to deal with less favourable socio-economic and institutional environments. They face increased - often biased - competition from new actors and activities. Indeed, as this article shows, renewed foreign investor interest in land acquisition and the related questions of ownership and land tenure represent only one aspect of the impact felt by African communities. The changing structure of agricultural production that results from these investors' production and investment models goes beyond the issue of the land itself. The rush for land and the resulting commercial pressures on land relate to profound agrarian transformations, characterised by a corporatisation and financialisation of agricultural practices. The outcome is associated with a trend towards concentration and intensification, with the marginalisation of family farming and the proletarisation of farmers, who are becoming rent-seekers or landless labourers. Even where the land rush could lead to increased productivity, there are real concerns that the most vulnerable groups will bear the costs without reaping the benefits and that the host economies are not effectively benefiting from it. 
These observations help to sketch the renewed political economy in which these transformations take place, ranging from new investor strategies to changing geopolitical contexts - emergent economies' strategies and the role of agriculture, new dynamics in North-South relations, the question of elite capture, to name but a few. This debate takes us to the crossroads between increasing agricultural production and responsible, sustainable and equitable investments, assessed from a socioeconomic and political angle. ${ }^{68}$

Questions are also raised about the trajectory of agricultural development on the continent, in a context of increased pressure on natural resources and the environment. In such a context, the limitations of a green revolution might well only be reached once it has become destructive from an environmental angle, thus emphasising the need for alternative approaches. ${ }^{69}$ These concerns underlie present agricultural development tensions, taking us back to the debate between small-scale agriculture and large mechanised operations, to the rise of productivity in an agroecological sustainable manner, but also to the increase of the role for African smallholders and the place of African agriculture in an emerging global production system.

Several instruments endeavouring to regulate land investments, incorporating both the socio-economic and environmental aspects, are currently under development. They range from minimum human rights principles as guidance in adjudicating large-scale land acquisitions ${ }^{70}$ to guidelines and principles in land investments at the global level. ${ }^{71}$ These instruments are strongly criticised. Some note that their effectiveness will remain limited as long as the rights of local populations - including of course their land rights, but also basic democratic rights - are not recognised and respected in the host countries, where authorities often do not allow populations free and prior informed consent to land transactions. ${ }^{72}$ Others criticise their voluntary nature, which leads not only to weak implementation potential but also to the danger of legitimising the 'land grab' phenomenon. ${ }^{73}$

However, despite these criticisms, in the absence of genuine alternative successful investment and production models, agricultural development centred on large-scale land investments has become the reigning paradigm. While this paradigm is being adopted by capital-poor African countries trying to attract private, national and international capital with the aim of overcoming the lack of investment for their discarded agricultural and rural sectors, the model appears also to be indirectly promoted by public development agencies (e.g. NEPAD ${ }^{74}, \mathrm{AFDB}^{75}$ ), as they support the establishment of large-scale investments funds. This support, particularly, underlines the lack of reflection and debate around the implications for developing countries of the current transformation in African agriculture, and of national and international development policies and trajectories, whether agricultural or not.

\section{Notes on contributor}

Dr Ward Anseeuw, a development economist and policy analyst, is currently a Research Fellow at the Agricultural Research Centre for International Development (CIRAD) seconded to the Post-Graduate School of Agriculture and Rural Development of the University of Pretoria. He has conducted research for the last 15 years in Southern Africa and the African continent more generally. His area of interest and research includes agricultural and land policies, agrarian and land reforms, land conflicts and large-scale land acquisitions. His recent publications on these issues include Land, transition and compromise (with Chris Alden, Palgrave, 2009), The struggle over land in Africa - Conflicts, politics and change (with Chris 
Alden, HSRC Press, 2010) and South Africa's Agrarian Reform (In French, Editions Universitaires Européennes, 2011).

\section{Notes}

1. Cotula L, Vermeulen S, Leonard R \& J Keeley, 'Land grab or development opportunity? Agricultural investment and international land deals in Africa'. Research report. London/Rome: IIED/FAO/IFAD, 2009; Deininger K \& D Byerlee, 'Rising global interest in farmland. Can it yield sustainable and equitable benefits?' Research report. Washington, DC: The World Bank, 2010; Anseeuw W, Alden Wily L, Cotula L \& M Taylor, 'Land rights and the rush for land'. Research report. Rome: International Land Coalition, 2012. Also see several special issues of the Journal of Peasant Studies, 38, 2, 2011; 39, 5, 2012, etc.

2. UNCTAD. 'Rapport sur l'investissement dans le monde: sociétés transnationales, production agricole et développement en 2009'. Rapport - Vue d'ensemble. New York, UNCTAD, 2009.

3. FAO. Global Agriculture Towards 2050. High Level Forum - How to Feed the World in 2050, 12-13 October 2009. Rome: FAO, 2009.

4. Green revolution here refers to policies intended to increase agricultural yields to address food insecurity issues, specifically, and not to the general campaign to address climate change and other environmental degradation effects.

5. See www.landportal.info/landmatrix

6. See www.commercialpressuresonland.org

7. The Land Matrix. Large-scale Land Acquisitions in the World. The Land Matrix Partnership (CDE, CIRAD, GIGA, GIZ, ILC), 2011.

8. Deininger $\mathrm{K}$ and D Byerlee, 'Rising global interest in farmland. Can it yield sustainable and equitable benefits?' Research report. Washington, The World Bank, 2010.

9. The Land Matrix. Large-scale Land Acquisitions in the World. The Land Matrix Partnership (CDE, CIRAD, GIGA, GIZ, ILC), 2011.

10. Anseeuw W, Boche M, Breu T, Giger M, Lay J, Messerli P \& K Nolte, 'Transnational land deals for agriculture in the Global South. Analytical Report based on the Land Matrix Database'. Research report. Bern/Montpellier/Hamburg, CDE/CIRAD/GIGA, 2012.

11. Anseeuw W, Alden Wily L, Cotula L \& M Taylor, 'Land rights and the rush for land'. Research report. Rome: International Land Coalition, 2012.

12. Alden Wily L, 'The tragedy of public lands: The fate of the commons under global commercial pressure'. Alden Wily contribution to ILC Collaborative Research Project on Commercial Pressures on Land, Rome, 2011.

13. Fisseha M, 'A case study of the Bechera agricultural development project, Ethiopia'. Fisseha contribution to ILC Collaborative Research Project on Commercial Pressures on Land, Rome, 2011.

14. Cotula L, 'The international political economy of the global land rush: A critical appraisal of trends, scale, geography and drivers', The Journal of Peasant Studies, 39, 3-4, 2012, pp. 649-80.

15. Anseeuw W, Boche M, Breu T, Giger M, Lay J, Messerli P \& K Nolte, 'Transnational land deals for agriculture in the Global South. Analytical Report based on the Land Matrix Database'. Research report. Bern/Montpellier/Hamburg, CDE/CIRAD/GIGA, 2012.

16. Anseeuw W, Alden Wily L, Cotula L \& M Taylor, 'Land rights and the rush for land'. Research report. Rome: International Land Coalition, 2012.

17. Deininger K and D Byerlee, Rising Global Interest in Farmland. Can it Yield Sustainable and Equitable Benefits? Research report. Washington, The World Bank, 2010.

18. The Land Matrix. Large-scale Land Acquisitions in the World. The Land Matrix Partnership (CDE, CIRAD, GIGA, GIZ, ILC), 2011.

19. Ibid.

20. Among other, see Hall R, 'The next Great Trek? South African commercial farmers move north', Journal of Peasant Studies, 39, 3-4, 2012, pp. 823-43; Brautigam D \& 
T Xiaoyang, 'African Shenzhen: China's special economic zones in Africa', Journal of Modern African Studies, 49, 1, 2011, pp. 27-54.

21. GRAIN, Land Grabs and Food Sovereignty. Benin: Atelier régional des O.S.C. sur l'accaparement des terres en Afrique de l'Ouest, 8-9 février 2012, <www.grain.org/ articles/ 4575-land-grabbing-and-food-sovereignty-in-west-and-central-africa.pdf $>$.

22. Ducastel A \& W Anseeuw, 'Le "production grabbing" et la transnationalization de l'agriculture (sud-) africaine', Transcontinentales, 10/11, 2011, <http://transcontinentales.revues.org/1080>.

23. Boche M, Anseeuw W, Kapuya T, Aubin S \& I Sunga, 'Global land deals: Land based investment models and agrarian restructuration in Southern Africa', in Global Land Grabbing II Conference, 17-19 October 2012. Ithaca, NY: Cornell University.

24. Buxton A, Campanale M \& L Cotula, 'Farms and funds: Investment funds in the global land rush'. London: IIED Briefing Papers, January 2012.

25. Devèze JC, Défis Agricoles Africains. Paris: Karthala-AFD, 2008.

26. Boche M, Anseeuw W, Kapuya T, Aubin S \& I Sunga, 'Global land deals: Land based investment models and agrarian restructuration in Southern Africa', in Global Land Grabbing II Conference, 17-19 October 2012. Ithaca, NY: Cornell University.

27. Ibid.

28. Reardon $\mathrm{T} \& \mathrm{CB}$ Barrett, 'Agroindustrialization, globalization and international development: an overview of issues, patterns and determinants', Agricultural Economics, 23, 3, 2000, pp. 195-205.

29. Rabobank International, 'New models of farming in Argentina'. Rabobank Industry Note, 1 December 2011.

30. De Schutter O, 'The global food crisis and the right to food. Brussels'. PES Comité des Régions, Presentation, 21 April 2009.

31. O'Brien E, 'Irregular and illegal land acquisition by Kenya's elites: Trends, processes, and impacts of Kenya's land grabbing phenomenon'. ILC Collaborative Research project on Commercial Pressures on Land, Rome, 2011.

32. Cotula L, Vermeulen S, Leonard R \& J Keeley, 'Land grab or development opportunity? Agricultural investment and international land deals in Africa'. Research report. London/Rome: IIED/FAO/IFAD, 2009.

33. Greco E, 'Struggles and resistance against land dispossession in Africa: An overview', in Allan T, Keulertz M, Sojamo S \& J Warner (eds), Handbook of Land and Water Grabs in Africa. London: Routledge, 2013, pp. 456-68.

34. Baxter $\mathbf{J}$, 'Understanding land deals in Africa'. Country report, Mali. Oakland: The Oakland Institute, 2011; Andrianirina-Ratsialonana R, Ramarojohn L, Burnod P \& A Teyssier, 'After Daewoo? Current status and perspectives of large scale land acquisitions in Madagascar'. OF/CIRAD contribution to ILC Collaborative Research Project on Commercial Pressures on Land, Rome, 2011.

35. Brautigam D \& T Xiaoyang, 'African Shenzhen: China's special economic zones in Africa', Journal of Modern African Studies, 49, 1, 2011, pp. 27-54.

36. Cotula L, 'The international political economy of the global land rush: A critical appraisal of trends, scale, geography and drivers', The Journal of Peasant Studies, 39, 3-4, 2012, pp. 649-80.

37. Veldman M \& M Lankhorst, 'Socio-economic impact of commercial exploitation of Rwandan Marshes: A case study of sugar cane production in rural Kigali'. RCN contribution to ILC Collaborative Research Project on Commercial Pressures on Land, Rome, 2011.

38. Yaw Baah A \& H Jauch (eds), 'Chinese Investments in Africa: A Labour Perspective'. Research report. Johannesburg: African Labour Research Network, 2009.

39. On the labour issue, see Murray Li T, 'Centering labor in the land grab debate', Journal of Peasant Studies, 38, 2, 2012, pp. 281-98.

40. Anseeuw W, Alden Wily L, Cotula L \& M Taylor, 'Land rights and the rush for land'. Research report. Rome: International Land Coalition, 2012.

41. Rawat VB, Bhushan MB \& S Sujata, 'The impact of special economic zones in India: A case study of Polepally SEZ'. SDF contribution to ILC Collaborative Research Project on Commercial Pressures on Land, Rome, 2011. 
42. Alden Wily L, 'The tragedy of public lands: The fate of the commons under global commercial pressure'. Alden Wily contribution to ILC Collaborative Research Project on Commercial Pressures on Land, Rome, 2011.

43. Odhiambo MO, 'Commercial pressures on land in Africa: A regional overview of opportunities, challenges, and impacts'. RECONCILE contribution to ILC ILC Collaborative Research Project on Commercial Pressures on Land, Rome, 2011.

44. Anseeuw W, Boche M, Breu T, Giger M, Lay J, Messerli P \& K Nolte, 'Transnational land deals for agriculture in the Global South. Analytical Report based on the Land Matrix Database'. Research report. Bern/Montpellier/Hamburg, CDE/CIRAD/GIGA, 2012.

45. In this particular case, and in other examples where access to water is one of the key drivers of transnational land acquisitions, 'water grabbing' is being pinpointed. See Keulertz M, 'The new politics of virtual water in East Africa'. Presentation for the 'Land Deal Politics Initiative' International Conference on Global Land Grabbing, PDI Sussex paper, 2011; Allan T, Keulertz M, Sojamo S \& J Warner (eds), Handbook of Land and Water Grabs in Africa. London: Routledge, 2013.

46. Montemayor RQ, 'Overseas farmlands - Boon or bane for farmers in Asia?', in Kugelman M \& SL Levenstein (eds), Land Grab? The Race for the World's Farmland. Washington, DC: Woodrow Wilson International Center for Scholars, 2009.

47. Markelova $\mathrm{H} \& \mathrm{R}$ Meinzen-Dick, The importance of property rights in climate change mitigation'. 2020 Vision Briefs, 16, 10, 2009. International Food Policy Research Institute.

48. Molnar AK, Barney M, De Vito A, Karsenty D, Elson M, Benavides P, Tipula C, Soria P, Sherman P \& France M, 'Large acquisition of rights on forest lands for tropical timber concessions and commercial wood plantations'. Rights and Resources Initiative (RRI) contribution to ILC Collaborative Research Project on Commercial Pressures on Land, Rome, 2011.

49. Fisseha M, 'A case study of the Bechera agricultural development project, Ethiopia'. Fisseha contribution to ILC Collaborative Research Project on Commercial Pressures on Land, Rome, 2011.

50. Veldman M \& M Lankhorst, 'Socio-economic impact of commercial exploitation of Rwandan Marshes: A case study of sugar cane production in rural Kigali'. RCN contribution to ILC Collaborative Research Project on Commercial Pressures on Land, Rome, 2011.

51. Ducastel A \& W Anseeuw, 'Le "production grabbing" et la transnationalization de l'agriculture (sud-) africaine', Transcontinentales, 10/11, 2011, <http://transcontinentales. revues.org/1080>.

52. Palley TI, Financialization: What It Is and Why It Matters. Working Paper No. 525. Washington, DC: The Levy Economics Institute and Economics for Democratic and Open Societies, 2007.

53. HLPE, 'Price volatility and food security'. Rome: FAO, High Level Panel of Experts' report on price volatility, 2011.

54. Reardon $\mathrm{T} \& \mathrm{CB}$ Barrett, 'Agroindustrialization, globalization and international development: an overview of issues, patterns and determinants', Agricultural Economics, 23, 3, 2000, pp. 195-205.

55. Boche M, Anseeuw W, Kapuya T, Aubin S \& I Sunga, 'Global land deals: Land based investment models and agrarian restructuration in Southern Africa', in Global Land Grabbing II Conference, 17-19 October 2012. Ithaca, NY: Cornell University.

56. Reardon T, Christopher B, Barret CB, Berdegue A \& JFM Swinnen, 'Agrifood industry transformation and small farmers in developing countries', World Development, 37, 11, 2009, pp. 1717-27.

57. Ducastel A \& W Anseeuw, 'Le "production grabbing" et la transnationalization de l'agriculture (sud-) africaine', Transcontinentales, 10/11, 2011, <http://transcontinentales. revues.org/1080>.

58. Greenberg S, 'Status report on land and agricultural policy in South Africa'. Cape Town, PLAAS, Research Report No. 40, 2010. 
59. Losch, B., Freguin-Gresh S., White E.T. 'Structural transformation and rural change revisited: Challenges for late developing countries in a globalizing world', (Washington: World Bank, 2012).

60. Borras S, Kay C \& E Lahiff (eds), Market-Led Agrarian Reform: Critical Reflections on Neoliberal Land Policies and the Rural Poor. London: Routledge, 2008.

61. Anseeuw W, 'The end of the (South) African peasant? The Global Land Rush, New Investment Models and Agrarian Change', in 50th Annual Conference of the Agricultural Economics Association of South Africa 'Challenges beyond 50 Years of Agricultural Economics in South Africa', Bloemfontein, 1-3 October 2012, invited key note presentation.

62. Tanner C, 'Land rights and enclosures: implementing the Mozambican Land Law in Practice', in Anseeuw W \& C Alden (eds), The Struggle over Land in Africa: Conflict, Politics, Change. Cape Town: Human Sciences Research Council Press, 2010, pp. 105-30; Boche M, 'Processus d'acquisitions foncières à grande échelle: les modalités d'accès au foncier au Mozambique', Conference Paper, Journées Doctorales du Pôle Foncier, Montpellier, 22-25 Octobre 2012.

63. HLPE, Price Volatility and Food Security. Rome: FAO, High Level Panel of Experts' report on price volatility, 2011.

64. GRAIN, Land Grabs and Food Sovereignty. Benin: Atelier régional des O.S.C. sur

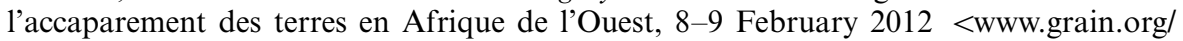
articles/ 4575-land-grabbing-and-food-sovereignty-in-west-and-central-africa.pdf $>$.

65. De Schutter O, 'Spéculation agricole et flambée des prix alimentaires. Réguler pour réduire les risques de volatilité'. Note d'information du Rapporteur spécial sur le droit à l'alimentation, Septembre 2010.

66. Pons-Vignon N \& W Anseeuw, 'Great Expectations: The evolutions of labour conditions since the end of apartheid', Journal of Southern African Studies, 35, 4, 2009, pp. 883-99.

67. Gaud WS, The Green Revolution: Accomplishments and Apprehensions. Washington, DC: Department of State, Agency for International Development, 1968.

68. Cotula L, 'The international political economy of the global land rush: A critical appraisal of trends, scale, geography and drivers', The Journal of Peasant Studies, 39, 3-4, 2012, pp. 649-80.

69. Griffon M, 'Révolution verte, révolution doublement verte. Quelles technologies, quelles institutions et quelle recherche pour les agricultures de l'avenir?' Montpellier, CIRAD, Nature, Sociétés et Développement durable, research paper, 2002; Griffon M, Nourrir la planète. Paris: Odile Jacob, 2006; Severino JM \& O Ray, Africa's Moment. London: Polity Press, 2012.

70. De Schutter O, 'Promotion and protection of human rights, civil, political, economic, social and cultural rights, including the right to development - Addendum: Large-scale land acquisitions and leases: a set of minimum principles and measures to address the human rights challenge'. The UN Human Rights Council. A/HRC/13/33/add.2, 2009.

71. To ensure so-called responsible agricultural investments, a 'code of conduct' has been proposed by the World Bank and the International Food Policy Research Institute (IFPRI) (2010). More recently, the FAO proposed the Voluntary Guidelines on the Responsible Governance of Tenure of Land (2012).

72. Alden Wily L, 'Whose Land Are You Giving Away, Mr. President?' Paper presented to the Annual Land Policy and Administration Conference. Washington, DC: World Bank, 2010.

73. Borras S \& J Franco, 'From threat to opportunity? Problems with the idea of a 'Code of Conduct' for land-grabbing', Yale Human Rights \& Development Journal, 13, 2010, pp. 507-23.

74. New Economic Partnership for African Development.

75. African Development Bank. 